\title{
Phagocytic Uptake of Polymeric Particles by Immune cells Under Flow Conditions
}

\author{
Megha Srinivas $^{1,2}$, Preeti Sharma ${ }^{1}$, Siddharth Jhunjhunwala ${ }^{1 *}$
}

1 - Centre for BioSystems Science and Engineering, Indian Institute of Science, Bengaluru 560012

2 - Undergraduate program, Indian Institute of Science, Bengaluru - 560012

* - Address correspondence to siddharth@iisc.ac.in

\begin{abstract}
Particles injected intravenously are thought to be cleared by macrophages residing in the liver and spleen, but they also encounter circulating immune cells. It remains to be established if the circulating cells can take up particles while flowing, and if the uptake capacity is similar under static and flow conditions. Here, we use an in vitro peristaltic pump setup that mimics pulsatile blood flow to determine if immune cells take up particles under constant fluidic flow. We use polystyrene particles of varying sizes as the model of a polymeric particle for these studies. Our results show that the immune cells do phagocytose under flow conditions. We demonstrate that cell lines representing myeloid cells, primary human neutrophils and monocytes take up submicrometer-sized particles at similar or better rates under flow compared to static conditions. Experiments with whole human blood show that even under the crowding effects of red blood cells, neutrophils and monocytes take up particles while flowing. Together, these data suggest that circulating immune cells are likely to phagocytose intravenously injected particulates, which has implications for design of particles to evade or target these cells.
\end{abstract}

Key Words: Neutrophils; Monocytes; Macrophages; Phagocytosis; Blood 


\section{Introduction}

A relatively small proportion of nano- and sub-micro-sized particles administered through the intravenous route reach their target cell or organ due to clearance by immune cells ${ }^{1-4}$. The removal of particles from circulation is thought to occur primarily through the phagocytic action of macrophages residing in the liver and spleen ${ }^{1,5}$. Enhanced clearance in the liver appears to be due to the presence of large numbers of phagocytic macrophages and lower blood flow velocity (and hence nanoparticle flow velocity) in the liver sinusoids ${ }^{6}$. However, there are several phagocytic immune cells in circulation, and it remains unclear how these cells interact with the intravenously injected particles.

Phagocytosis of particles by immune cells has primarily been studied using models where the cells and particles are static ${ }^{7-10}$, or when the cells are static, and the particles are flowing ${ }^{11-13}$. In comparison, uptake when both the cells and the particles are flowing remains poorly explored. Minasyan suggests that phagocytosis in the bloodstream is likely to be impossible due to the high velocity of blood flow, insufficient time for particulate capture and engulfment by immune cells, and crowding due to a large number of red blood cells ${ }^{14}$, though experiments to prove this have not been conducted. Contrastingly, Tsoi et al. ${ }^{6}$ have shown that peripheral blood mononuclear cells do phagocytose nanoparticles under flow conditions in vivo, but their phagocytic capacity may be lower than static conditions. Similarly, few other reports have also suggested that intravenously injected particles are associated with circulating immune cells. For example, Smith et al. ${ }^{15}$ show that single walled carbon nanotubes are preferentially taken up by circulating monocytes. Eniola-Adefeso and colleagues have also shown 0.5 and $2 \mu \mathrm{m}$ sized PLGA particles of varying shapes may be specifically taken up by neutrophils in circulation ${ }^{16,17}$. Recently, Zhang et al. ${ }^{18}$ showed that $250-900 \mathrm{~nm}$ sized poly (lactic-co-glycolic acid) nanoparticles are internalized by monocytes and myeloid derived suppressor cells following in tumor bearing mice. Studies on quantum dots and gold nanoparticles have shown that smaller sized particles $(<50 \mathrm{~nm})$ generally 
have higher circulation half-lives than larger sized particles, as they are less likely to be taken up macrophages in the liver and possibly circulating immune cells ${ }^{19}$. Intravenously injected bacteria and zymosan particles are also thought to be associated circulating immune cells ${ }^{20-22}$. While these reports suggest that uptake might occur under flow conditions, it does not prove it definitively. One possible alternate explanation is that the particles are taken up by stationary immune cells present in tissues (such as the liver or lung), which then enter circulation again ${ }^{23}$. Importantly, there has been no direct comparison of the phagocytic capacity of the same group of immune cells in static versus flow conditions, which might help to relatively quantify phagocytosis under flow conditions.

Herein, we sought to answer whether phagocytosis may occur when both cells and particles are flowing using an in vitro setup and directly comparing the phagocytic capacity of same cell-types when placed in static or flow conditions. We used a peristaltic pump to mimic the pulsatile nature of blood flow. Experiments on phagocytosis under flow conditions were conducted by varying flow rates from 0.1 to $10 \mathrm{ml} / \mathrm{min}$, which are in the range of flow rates observed in vivo ${ }^{24,25}$. Our results show that phagocytic immune do take up particles under flow conditions and that the level of uptake depends on cell type, particle size, and flow rate.

\section{Materials and Methods}

\section{$\underline{\text { Cell Lines }}$}

RAW 264.7 cells (Merck, USA) were cultured in DMEM complete media (DMEM (Cellclone and Lonza, India) containing 10\% fetal bovine serum (FBS, Thermofisher, USA) and antibiotics). Cells were passaged when the flasks were about $80 \%$ confluent. The HL-60 cells (ATCC, USA) were cultured in IMDM complete media (IMDM (Merck) containing 20\% FBS and antibiotics). Cells were passaged when the cells were at a concentration of 1 million cells in $1 \mathrm{ml}$. 


\section{Human Blood, Neutrophils and PBMCs}

Peripheral venous blood samples were obtained from healthy volunteers following the norms laid out by the Indian Institute of Science's ethics committee for research with human samples (IHEC No: 5-15032017 and 2-31082018) and with informed consent. The blood was collected in EDTAcoated tubes for purified-cell experiments and citrate, or EDTA-coated tubes for whole blood experiments. For isolating immune cells, the blood sample was loaded onto histopaque (density $1.077 \mathrm{~g} / \mathrm{ml}$, Merck, USA) gently and was spun down at $400 \mathrm{RCF}$ for $20 \mathrm{~min}$ at room temperature without brake. The buffy coat containing the PBMCs was carefully removed and subjected to RBC lysis for 3 minutes. The bottom-most layer containing the RBCs and neutrophils was subjected to RBC lysis for 9 minutes to obtain the neutrophils. The lysis was quenched with over two-fold volume of $1 \mathrm{X}$ PBS. Following quenching, the samples were spun down at $400 \mathrm{RCF}$ for 4 minutes at $4^{\circ} \mathrm{C}$. The supernatant was discarded, and the cells were suspended in DMEM complete media. The cells were counted using a hemocytometer.

\section{$\underline{\text { Particles }}$}

Polystyrene particles (Bangs Laboratories, USA) of varying sizes and labeled with different fluorophores were used as a model particle system. Volumetrically equivalent amounts of different particle sizes were used for the uptake studies. These approximately correspond to 1 particle (2.9 $\mu \mathrm{m}$ diameter $) \approx 200$ particles $(500 \mathrm{~nm}$ diameter $) \approx 3000$ particles $(200 \mathrm{~nm}$ diameter $)$ per cell. For studies involving RAW 264.7 cells and $500 \mathrm{~nm}$ particles, the ratios were 50 particles per cell.

\section{Uptake Studies under Static Conditions}

The cells were seeded in a 24-well plate at a concentration of 0.1 or 0.2 million cells per well. Adherent cells (RAW) were allowed to adhere for a minimum time of 1 hour, while semi-adherent to non-adherent cells (HL-60, neutrophils and peripheral blood mononuclear cells) were allowed to remain in the plate for $20-30 \mathrm{~min}$ at $37^{\circ} \mathrm{C}$. The peripheral blood mononuclear cells were used 
as is, and hence contained monocytes, B cells, T cells and other mononuclear cells. Separately, polystyrene particles (varying numbers depending on the particle size) were sonicated for 5 min and then added to the cells. At the specific time points ( 2 hours or 4 hours), the media was removed, and cells collected from the wells were washed and stained with propidium iodide (2 $\mu \mathrm{g} / \mathrm{ml}$ ) to distinguish live from dead and run on a flow cytometer (BD FACSCelesta).

\section{Uptake Studies under Flow Conditions:}

A Masterflex L/S easy load peristaltic pump (Cole-Parmer, India) was used for the peristaltic flow experiments along with platinum-cured Silicone Tubing (Sani-tech STHT-C-062-2, 1/16" x 3/16", Saint-Gobain, India) (Suppl. Fig. 1). The tubing was passivated with a filter-sterilized $1 \%$ bovine serum albumin in PBS solution for 30 min each time the experiment was performed. The tubing was sanitized with a $70 \%$ ethanol wash and a water wash before and after each run, followed by autoclaving. Cells (RAW, HL-60, human neutrophils, and human PBMC) were suspended at a concentration of 1 million cells $/ \mathrm{ml}$ in $1.2 \mathrm{ml}$ of the appropriate type of media in test-tubes and were not allowed to adhere. Particles at the appropriate numbers (depending on size) were pipetted into this tube, and the cell and particle suspension was immediately (usually within 1 minute) subjected to flow in the peristaltic pump at the desired flow rate. For injection experiments, particles were injected into the tubing using an insulin syringe-needle. At pre-specified times, the cells flowing through the peristaltic pump were collected, washed, and suspended in $500 \mu \mathrm{l}$ of $1 \mathrm{X}$ PBS. A small aliquot was taken for manual counting (using trypan blue to check for survival). The cell suspension was stained with propidium iodide $(2 \mu \mathrm{g} / \mathrm{ml})$ and run on the flow cytometer. To confirm that the particles had been internalized, trypan blue was added to the cell suspension (in addition to propidium iodide) containing buffer before running on the flow cytometer as trypan blue is known to quench the fluorescence signal of particles (with an excitation at $488 \mathrm{~nm}$ and emission at $510 \mathrm{~nm}$ wavelength) stuck to the membrane (and internalized particles are protected from the quenching). 


\section{Whole blood experiments}

Heparin $(20 \mathrm{IU} / \mathrm{ml})$ was added to the blood sample collected in citrate or EDTA coated tubes within $20 \mathrm{~min}$ of collection. Whole blood $(500 \mu \mathrm{l})$ was plated in a 24 -well plate and placed in the incubator at $37^{\circ} \mathrm{C}$ for $20 \mathrm{~min}$. Polystyrene particles $(500 \mathrm{~nm})$ were sonicated for $5 \mathrm{~min}$ and then added to the cells at an approximate ratio of 1:200 (cells to particles) according to the combined theoretical neutrophil (5 million/ml) and PBMC (2 million/ml) counts in the blood. Whole blood and particle suspension was subjected to flow in the peristaltic pump at the desired flow rate for 2 hours. The cells were then collected and subjected to RBC lysis for 8 min. The cells were spun down and resuspended in flow cytometry buffer (PBS containing 1\% BSA and 4mM EDTA), and were stained with antibodies against CD45 (clone 2D1, BD Biosciences, USA), CD14 (clone M5E2, BD Biosciences) and CD15 (clone HI98, BD Biosciences) for $20 \mathrm{~min}$ at $4^{\circ} \mathrm{C}$. Finally, the cell suspension was stained with propidium iodide $(2 \mu \mathrm{g} / \mathrm{ml})$ and run on the flow cytometer. All flow cytometry data analysis was performed using FlowJo (Treestar, USA).

\section{Statistics}

The analysis of data and plotting of graphs was done using GraphPad Prism 8 (GraphPad Software, USA). Scatter plot data is reported through a single mean value with a standard deviation. For comparison of two groups, paired Student's 't' test was used (pairing was based on experiment's date when cells were from the same passage or individual, and particle additions were from the same stock solution). One-way ANOVA followed by post - hoc Tukey test was used to compare multiple groups.

\section{Results}


Blood flows at different rates (and velocity) in the arteries, veins, and capillaries ${ }^{24}$. To mimic flow rates in each of these circulatory system locations, we chose to perform experiments at three different flow rates $-0.1,1$, and $10 \mathrm{ml} / \mathrm{min}(\sim 0.83 \mathrm{~mm} / \mathrm{s}, \sim 8.3 \mathrm{~mm} / \mathrm{s}$, and $\sim 83 \mathrm{~mm} / \mathrm{s})$. Under these conditions, we measured the uptake of polystyrene particles by immune cells and compared it to conditions where both cells and particles are stationary. Uptake was determined as the percentage of cells that have taken up particles (\% uptake, a measure of how many cells are phagocytic) and the number of particles per cell (average values based on intracellular fluorescence intensities represented as median fluorescence intensities or MFI). Further, as the peristaltic setup could not be placed inside a $37^{\circ} \mathrm{C}$ incubator, studies were performed at room temperature. We determined that for the short time-frame studies ( 2 hours), uptake at room temperature $\left(\sim 25^{\circ} \mathrm{C}\right)$ was slightly (and significantly) lower than $37^{\circ} \mathrm{C}$ for the adherent macrophage (RAW 264.7) cell line and not significantly different for the suspension myeloid (HL-60) cell line (Suppl. Fig. 2).

\section{Uptake by an adherent cell line}

The adherent mouse macrophage cell line, RAW 264.7 (RAW), is highly phagocytic across particle sizes under static conditions ${ }^{26}$. To determine this cell's ability to take up particles while flowing, we tested uptake using polystyrene particles of three different diameters $-200 \mathrm{~nm}, 500$ $\mathrm{nm}$, and $2900 \mathrm{~nm}$ (Suppl. Fig. 3). These studies were initially done when cells and particles were co-incubated for 2 hours. We observed that uptake under flow conditions was dependent on both particle size and flow rate (Figure 1). The $200 \mathrm{~nm}$ particles were taken up equally well under both static and flow conditions, and no significant differences were observed across flow rates (Figure $1 \mathrm{~A}$ and $1 \mathrm{~B})$. On the other hand, the percentage of cells that took up the $500 \mathrm{~nm}$ particles was significantly greater at $1 \mathrm{ml} / \mathrm{min}$ flow rate than the static condition and other flow rates (Figure 1C). However, the number of particles per cell was not different across flow rates and compared to the static condition (Figure 1D). 
Further, we observed that under flow conditions, the percentage of cells taking up larger $2900 \mathrm{~nm}$ $(2.9 \mu \mathrm{m})$ sized particles reduced significantly compared to static conditions but was not different across flow rates (Figure 1E). Nevertheless, the small number of cells that did take up $2900 \mathrm{~nm}$ particles under flow conditions could phagocytose a similar number of particles as static conditions (Figure 1F). Together, these data show that adherent macrophages' capacity to take up smaller particles (200 and $500 \mathrm{~nm}$ ), but not larger particles (2900 nm), under flow conditions remains similar (if not greater) to static conditions. Additionally, flow rates do not appear to influence particle uptake, except for particles that are $500 \mathrm{~nm}$ sized, where the specific flow rate of $1 \mathrm{ml} / \mathrm{min}$ may be more suited for particle uptake as compared to other flow rates.

\section{$\underline{\text { Uptake Kinetics }}$}

Having observed differences in uptake across flow rates at 2 hour post co-incubation, we next evaluated the kinetics of uptake under static and flow conditions. For these experiments, RAW macrophages were incubated with $500 \mathrm{~nm}$ polystyrene particles for $5 \mathrm{~min}, 15 \mathrm{~min}, 30 \mathrm{~min}, 60 \mathrm{~min}$ or $240 \mathrm{~min}$ at all 3 flow rates (and under static conditions). We observed that for all flow rates, the association of particles with cells was similar to (not statistically significant differences) or higher (statistically significant) under flow conditions compared to static conditions at $5 \mathrm{~min}, 15 \mathrm{~min}, 30$ min and $60 \mathrm{~min}$ (Figure 2A and 2B). The kinetics of recognition and internalization of particles through the phagocytic process are suggested to be in the order of minutes ${ }^{27,28}$, and hence at the early time points (5 and $15 \mathrm{~min}$ ) we describe only association events under both static and flow conditions. By 30 min most of the particles were internalized by cells in flow and static conditions, which was confirmed using confocal microscopy (Suppl. Fig. 4) and measuring uptake through flow cytometry while using trypan blue to quench the signal from particles on the surface of a cell. Additionally, we observed that by 4 hours the uptake under static conditions has increased and become equal to or greater than uptake in flow conditions. These data suggest the kinetics of particle-cell interaction may be higher when cells and particles are both flowing, resulting in higher 
bioRxiv preprint doi: https://doi.org/10.1101/2021.04.01.438153; this version posted September 28, 2021. The copyright holder for this preprint (which was not certified by peer review) is the author/funder, who has granted bioRxiv a license to display the preprint in perpetuity. It is made available under aCC-BY-NC 4.0 International license.

number of cells associating with particles at early time points ( $5-30 \mathrm{~min})$, but given enough time ( 2 and 4 hours) the overall uptake under both static and flow conditions is similar (Suppl. Fig. 5). 

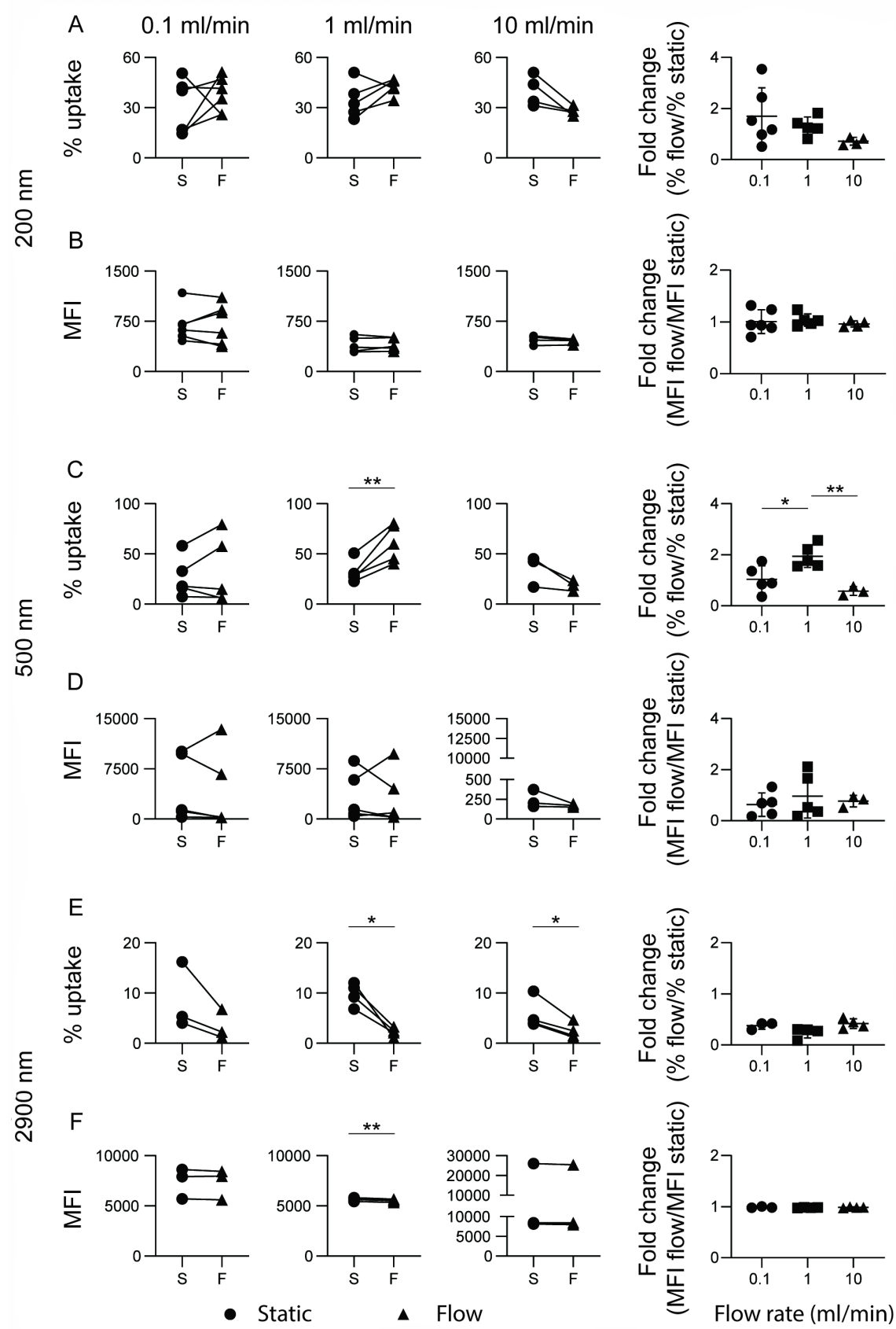

Figure 1: Phagocytosis by the adherent macrophage cell-line (RAW 264.7) at various flow rates. Uptake of $200 \mathrm{~nm}$ (A and B) or $500 \mathrm{~nm}$ (C and D) or $2900 \mathrm{~nm}$ (E and F) polystyrene particles plotted as either percentage uptake or particles per cell measured as median fluorescence intensity (MFI). Cell to particle ratio of 1:3000 $(200 \mathrm{~nm})$ or 1:50 $(500 \mathrm{~nm})$ or 1:1 $(2900 \mathrm{~nm})$ was used. Data represent results of $n \geq 3$ independent experiments, and the connecting lines indicate paired experiments. A paired Student's 't' test was performed to determine statistical differences between two groups and a one-way ANOVA followed by post-hoc Tukey test was performed to determine statistical differences between multiple groups. ${ }^{*}=p<0.05,{ }^{* *}=p<0.01$, and non-significant when no notation. 

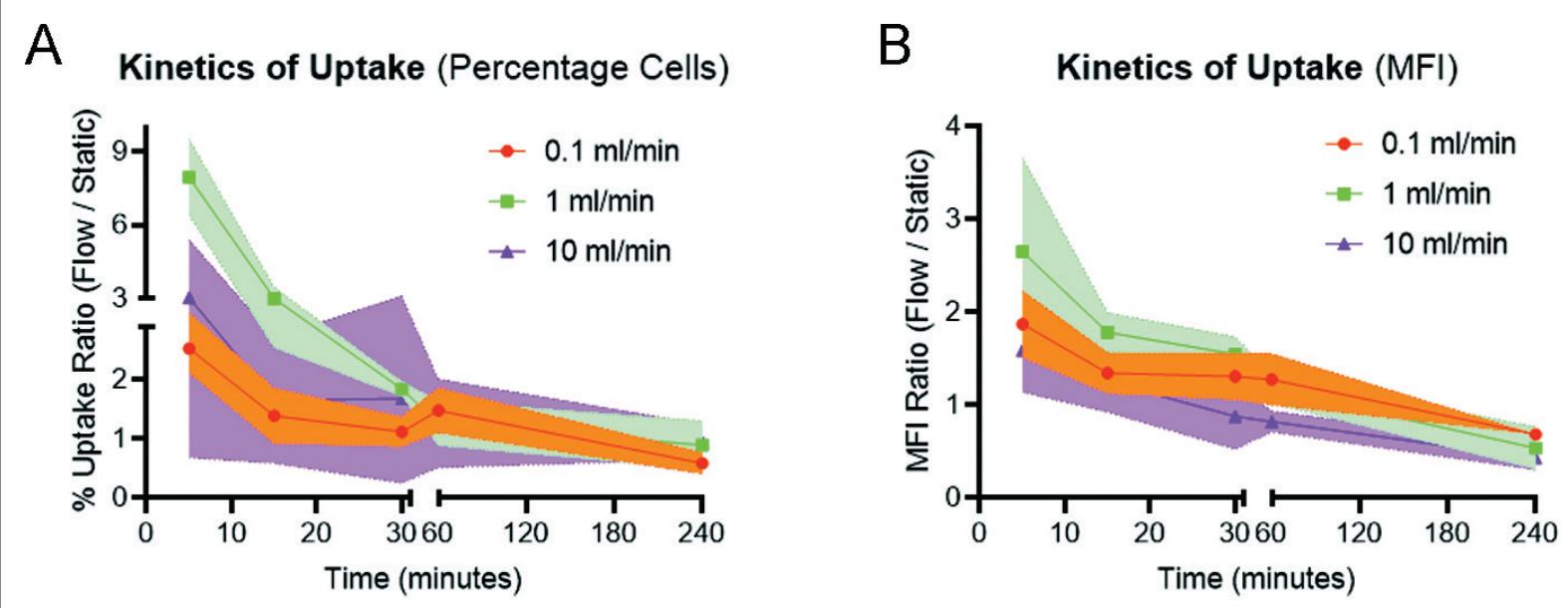

\begin{tabular}{|c|c|c|c|}
\hline & $0.1 \mathrm{ml} / \mathrm{min}$ & $1 \mathrm{ml} / \mathrm{min}$ & $10 \mathrm{ml} / \mathrm{min}$ \\
\hline $5 \mathrm{~min}$ & 0.009 & 0.064 & 0.035 \\
\hline $15 \min$ & 0.276 & 0.052 & 0.294 \\
\hline $30 \mathrm{~min}$ & 0.417 & 0.017 & 0.786 \\
\hline $60 \mathrm{~min}$ & 0.590 & 0.327 & 0.335 \\
\hline $240 \mathrm{~min}$ & 0.043 & 0.120 & 0.925 \\
\hline
\end{tabular}

\begin{tabular}{|c|c|c|c|}
\hline & $0.1 \mathrm{ml} / \mathrm{min}$ & $1 \mathrm{ml} / \mathrm{min}$ & $10 \mathrm{ml} / \mathrm{min}$ \\
\hline $5 \min$ & 0.0275 & 0.119 & 0.306 \\
\hline $15 \min$ & 0.100 & 0.051 & 0.313 \\
\hline $30 \mathrm{~min}$ & 0.174 & 0.117 & 0.371 \\
\hline $60 \mathrm{~min}$ & 0.223 & 0.251 & 0.051 \\
\hline $240 \mathrm{~min}$ & 0.100 & 0.009 & 0.048 \\
\hline
\end{tabular}

Figure 2: Kinetics of particle uptake. A - Ratio (flow/static) of percentage of cells with particles and B - ratio (flow/static) of particles per cell (denoted as median fluorescence intensity (MFI)) after 5,15 , 30,60 and 240 minutes of co-incubation of polystyrene particles with cells. Symbols indicate the mean value of $n \geq 3$ independent experiments and the shaded regions denote the standard deviation around those symbols. A paired ' $t$ ' test was performed at each time point and $p$ values are summarized in the table below the graph.

\section{Uptake by a non-adherent cell line}

Next, we sought to determine whether cells grown in suspension cultures would also behave similarly to an adherent cell line. We used HL-60 cells ${ }^{29,30}$, a human promyeloblast cell line for these studies, and used a higher ratio of particles to cells as these cells are less phagocytic. We observed that uptake by HL-60 cells also changed based on the size of the particle and flow rate, but the data were different from RAW cell uptake. Among the smaller particles $(200 \mathrm{~nm}$ and 500 $\mathrm{nm})$, uptake under static and flow conditions were similar at lower flow rates $(0.1$ and $1 \mathrm{ml} / \mathrm{min})$. However, uptake was significantly lower at the highest flow rate of $10 \mathrm{ml} / \mathrm{min}$ (Figure 3A, 3B, 3C and 3D). This data indicates that this cell line cannot engulf particles at flow rates that 
bioRxiv preprint doi: https://doi.org/10.1101/2021.04.01.438153; this version posted September 28, 2021. The copyright holder for this preprint (which was not certified by peer review) is the author/funder, who has granted bioRxiv a license to display the preprint in perpetuity. It is made available under aCC-BY-NC 4.0 International license.

approximately correspond to flow in large veins or smaller arteries. For the larger-sized particle $(2900 \mathrm{~nm})$, the percentage of cells with particles was low under both static and flow conditions (Suppl. Fig. 6), but the differences between the two were minimal (Figure 3E and 3F). 


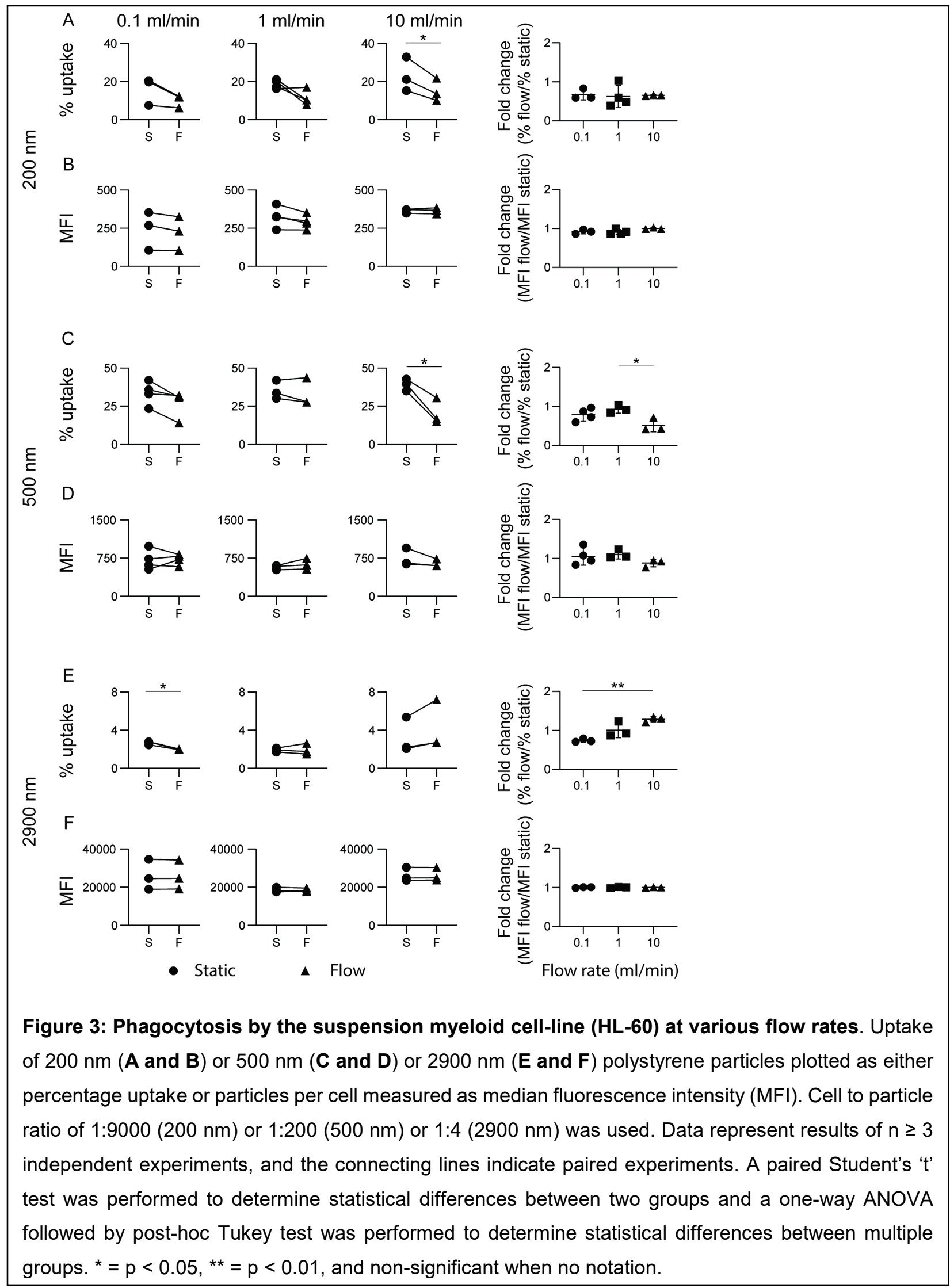




\section{Uptake by primary cells}

The cell line data suggest that particle internalization is possible under flow conditions, but cell lines may not entirely mimic primary cells ${ }^{31}$. Hence, we sought to determine if the observations held for cells isolated from human peripheral venous blood. For these studies, particles of one

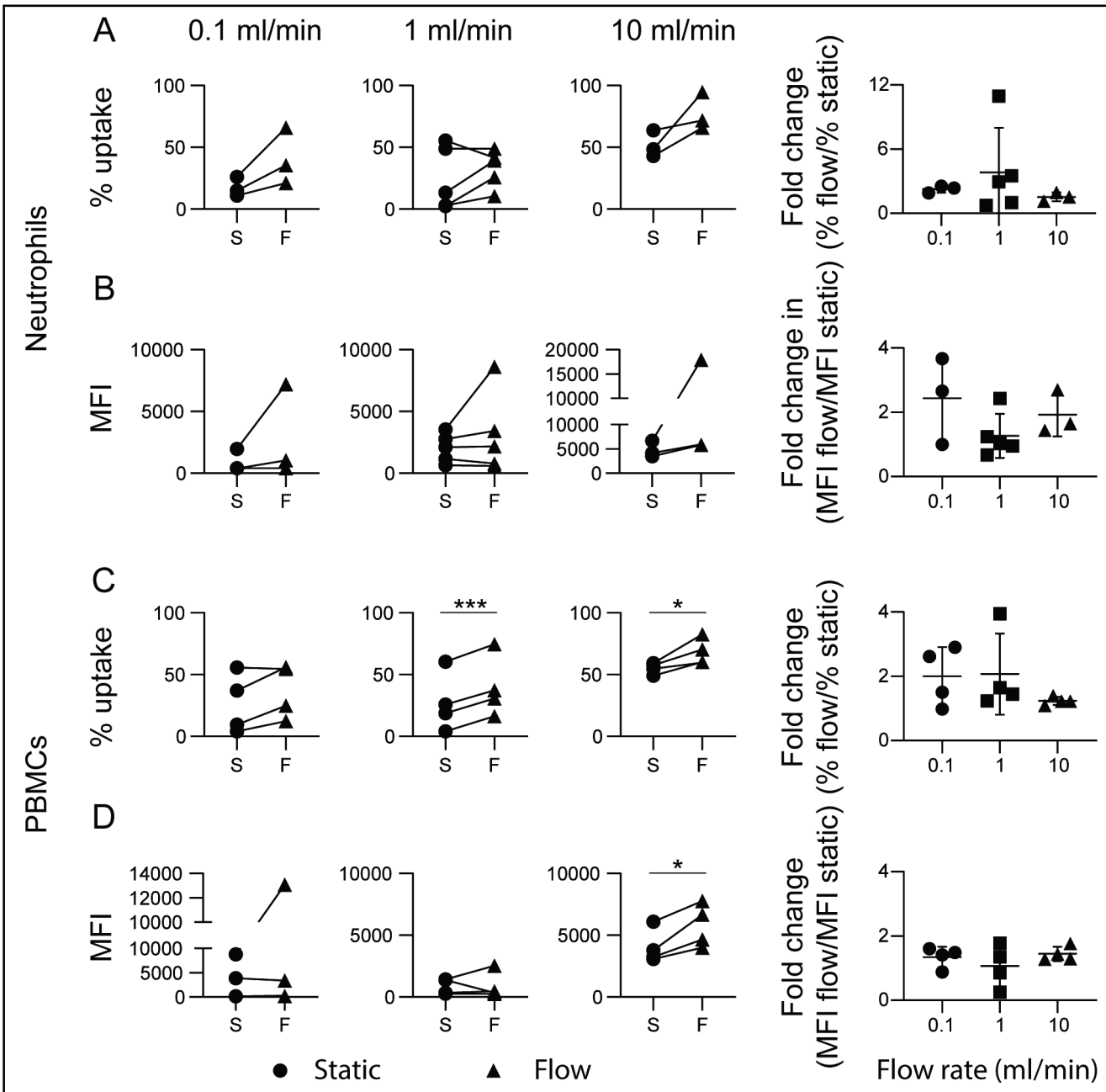

Figure 4: Phagocytosis by human neutrophils and PBMCs. Uptake of $500 \mathrm{~nm}$ polystyrene particles by neutrophils ( $A$ and $\mathbf{B}$ ) or PBMCs ( $\mathbf{C}$ and $\mathbf{D})$ isolated from peripheral venous blood draws, plotted as either percentage uptake or particles per cell measured as median fluorescence intensity (MFI). Cell to particle ratio of 1:200 was used. Data represent results of $n \geq 3$ independent experiments, and the connecting lines indicate paired experiments. A paired Student's ' $t$ ' test was performed to determine statistical differences between two groups and a one-way ANOVA followed by post-hoc Tukey test was performed to determine statistical differences between multiple groups. ${ }^{*}=p<0.05,{ }^{* * *}=p<0.001$, and non-significant when no notation. 
size $(500 \mathrm{~nm})$ were used. Specific immune cells were purified using density gradient centrifugation, and isolated cell populations were subjected to phagocytosis studies under static and flow conditions. We observed that neutrophils took up particles slightly, but not significantly, better under flow than static conditions (Figure 4A, Suppl. Fig. 7). A similar trend was observed for the number of particles per cell (Figure 4B). On the other hand, peripheral blood mononuclear cells (PBMCs) showed a significantly increased percentage of cells with particles at 1 and 10 $\mathrm{ml} / \mathrm{min}$ compared to static conditions (Figure 4C, Suppl. Fig. 7). Additionally, these cells also took up more particles per cell at the highest flow rate of $10 \mathrm{ml} / \mathrm{min}$ (Figure 4D). Nevertheless, the differences were not significant when comparing across flow rates (Figure 4C and 4D).

\section{Whole blood experiments}

While the data from purified primary cells suggests that uptake does occur under flow conditions, whole blood is a crowded environment where red blood cells outnumber the phagocytic immune cells by over a thousand to one. Such crowding affects the flow of cells and particulates ${ }^{32}$, which in turn might affect phagocytosis. To determine if uptake occurs under crowded conditions, particles were added to whole blood, and uptake was measured under both flow and static conditions. After co-culture for two hours, cells were stained with antibodies to identify neutrophils and monocytes (Suppl. Fig. 8), and the uptake was measured. Interestingly, neutrophils from whole blood were better at taking up particles under flow conditions compared to static conditions at $0.1 \mathrm{ml} / \mathrm{min}$ (significantly better) and $1 \mathrm{ml} / \mathrm{min}$ (trending higher but no significant difference) flow rates (Figure $5 \mathrm{~A}$ ). At the higher flow rate of $10 \mathrm{ml} / \mathrm{min}$, this difference was no longer observed, with neutrophils taking up particles equally well under static and flow conditions (Figure 5A). Similar to the observations in most cell line and purified primary cell studies, the total number of particles per cell did not appreciably change at any flow rate compared to static conditions (Figure $5 B)$. Another observation from these studies was that the overall uptake of purified neutrophil 
populations was higher than neutrophils in whole blood, under both flow and static conditions.

Such lowering could be due to a reduced chance of a neutrophil encountering a particulate ${ }^{31}$.

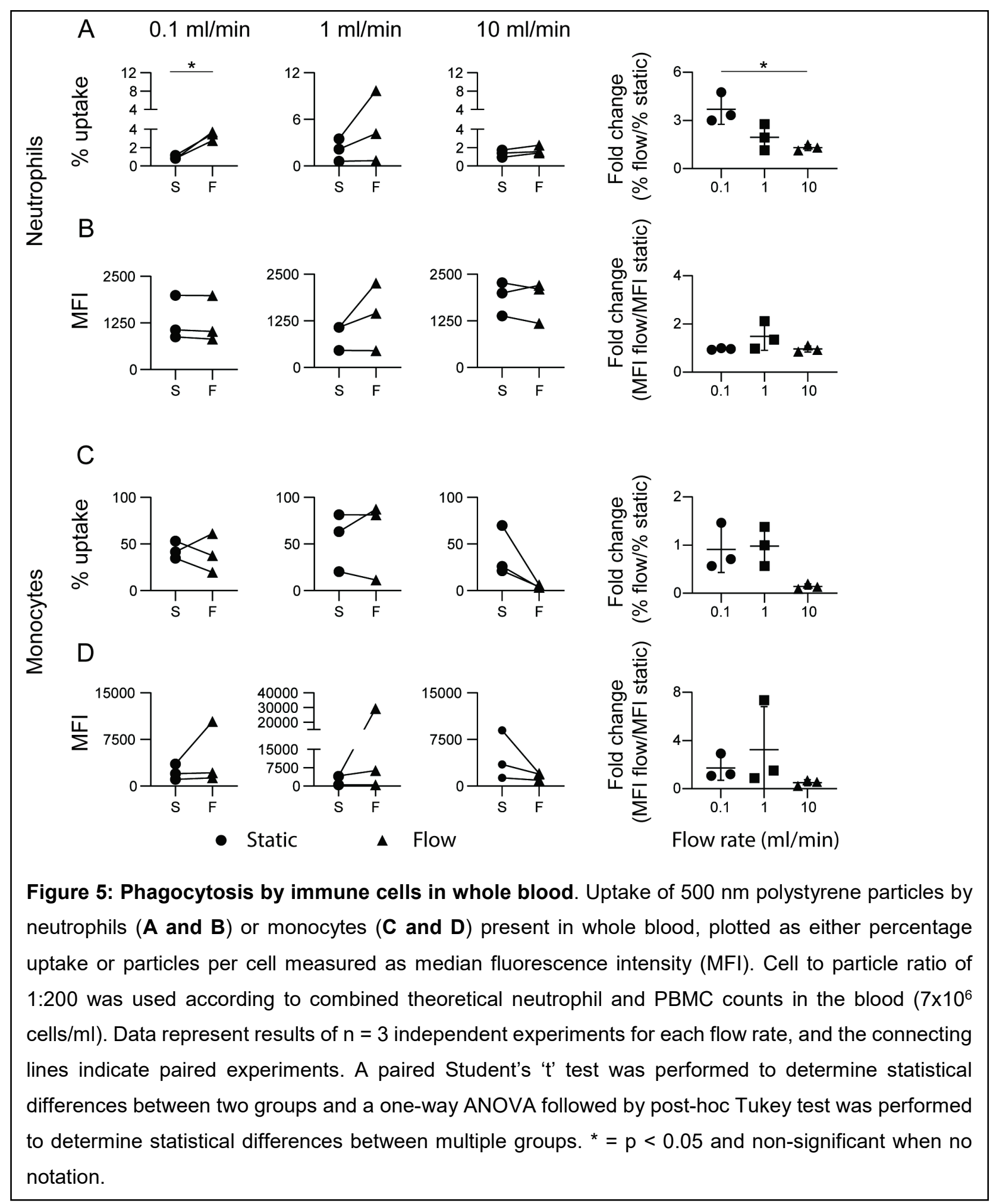


In comparison, monocytes from whole blood showed similar uptake at the lower flow rates of 0.1 and $1 \mathrm{ml} / \mathrm{min}$ and static conditions (Figure $5 \mathrm{C}$ ). However, they did show a propensity to have lower uptake at the higher flow rate of $10 \mathrm{ml} / \mathrm{min}$ compared to static conditions, but these differences were not statistically different in our studies with a limited number of samples (Figure 5C). This trend continued for the number of particles per cell, with similar numbers observed at 0.1 and $1 \mathrm{ml} / \mathrm{min}$ but lower at $10 \mathrm{ml} / \mathrm{min}$ flow rate (Figure 5D).

\section{Mimicking Clinical Conditions}

Mixing of particles with cells prior to subjecting them to peristaltic flow (even if the mixing occurred only for a minute or so) does not accurately represent conditions similar to in vivo administration of particles in to the blood stream. In order to replicate such conditions, we began by subjecting RAW macrophages to peristaltic flow for 5 minutes, followed by injection of $500 \mathrm{~nm}$ polystyrene particles into the tubing in which cells were flowing. Uptake was measured $30 \mathrm{~min}$ following the injection of particles. Even in these experiments, we observed that the

\section{Mimicking Injections}
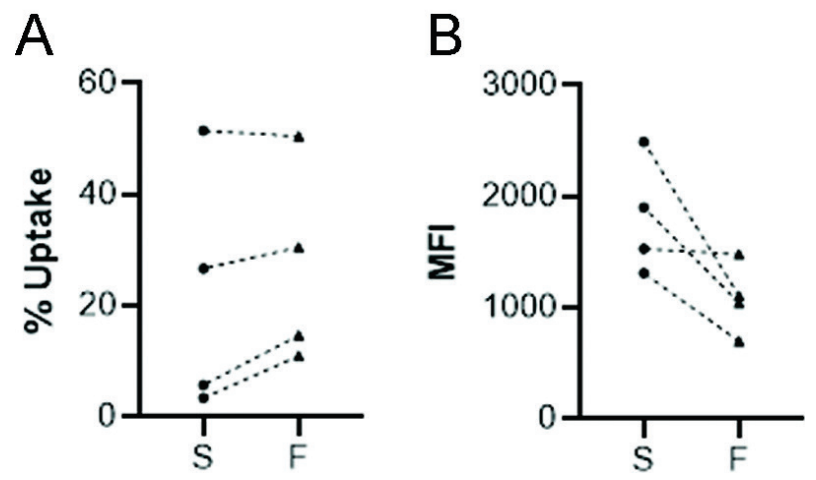

Figure 6: Phagocytosis following in vitro injection-like conditions. Uptake of $500 \mathrm{~nm}$ polystyrene particles by RAW macrophages following injection of the particles into the tubing were cells were flowing at $1 \mathrm{ml} / \mathrm{min}$ (flow conditions or "F") compared to static ("S") conditions, plotted as either percentage uptake $(A)$ or particles per cell measured as median fluorescence intensity or MFI (B). Data represent results of $n=4$ independent experiments. A paired Student's ' $t$ ' test was performed to determine statistical differences, and data were non-significant.

percentage of cells taking up particles under static and flow conditions were similar (Figure 6A) and while the number of particles per cell lower in flow conditions, the difference was not statistically significant (Figure 6B). This experiment further demonstrates that the uptake capacity of immune cells in flow is similar to that of static conditions. 


\section{Discussion}

The uptake of particles via one of the endocytic processes occurs in a series of steps ${ }^{33,34}$. The first step involves immune cells coming in contact with the particle they intend to take up, which has been thought to occur when the cell crawls towards the particulate substance ${ }^{35}$. The next step is the formation of membrane extensions that engulf the target ${ }^{28}$. And the final steps are the internalization of the particle in an endosomal vesicle. It is believed that the processes of cell crawling and extending its membrane around a particle are more likely when there is minimal to no flow involved. Additionally, it has been suggested that these same cellular processes may also occur when the cell is stationary while the particle is flowing, with the particle's size and shape influencing the frequency of interactions ${ }^{36}$. However, it remains unclear if the particulate uptake processes mentioned above $\mathrm{e}^{28,35}$ apply to the condition where both cells and particles are flowing.

Our data shows that uptake does occur when both cells and particles are flowing. How this might happen in the light of the established models of endocytosis is to be determined. We speculate that flow conditions might increase the number of random interactions (collisions) between cells and particles. Preliminary evidence for this statement is our data on high particle-cell association at 5 and 15 minutes post interaction under flow conditions, and reduced uptake by neutrophils and monocytes under crowded conditions of whole blood (where productive collision events will be lower) than uptake levels of purified populations of the same cells.

Interactions form only the first step of the uptake process. In the next stage of engulfment, cells must extend their membrane around the particle. This step involves cytoskeletal rearrangements ${ }^{37}$, and whether such changes occur under flow conditions needs to be explored further. Our data of equivalent or higher uptake of the smaller (200 and $500 \mathrm{~nm}$ ) sized particles under flow conditions suggest that cytoskeletal rearrangement might occur in these conditions. 
Similarly, lower uptake of the larger $(2900 \mathrm{~nm})$ particles might mean that even if such cytoskeletal reorganization occurs, they are likely limited and cannot engulf large particles.

Another aspect that affects uptake of particles is shear stress. Several studies have shown that shear stress is critical for cellular uptake of particles ${ }^{13,38,39}$. For example, Schubert and colleagues have shown that there is a positive correlation between shear stress and methacrylate nanoparticle uptake by adherent HUVEC cells ${ }^{38}$. Prina-Mello and colleagues have shown that the cellular uptake of particles is higher at low shear stress compared to static conditions ${ }^{39}$. Contrastingly, Ghandehari and colleagues have shown reduced uptake of silica nanoparticles by adherent RAW 264.7 macrophages under shear flow conditions compared to static conditions ${ }^{13}$. However, such shear stresses are only observed when the cells are stationary and bound to the culture surface, a condition common to all the aforementioned studies. In the work presented here, as both the particles and cells are flowing, and we have non-laminar flow, we expect the shear forces to be very different, but have not specifically measured them.

The protein corona on the particle surface has been shown to influence the ability of phagocytic cells to take up the particles ${ }^{40}$. It has also been shown that the type and quantity of proteins adsorbing on to nanoparticle surfaces under shear flow conditions are likely to be different ${ }^{41,42}$. In our studies, we incubate the particles with cells (under both static and flow conditions) in cell culture solution that contains fetal bovine serum. Hence, it is likely that the type and quantity of proteins adsorbing onto the particle surfaces are influencing the results we observe with regard to uptake under flow conditions.

Finally, the data presented here is for particles made of one material (polystyrene). The results of uptake by cells while flowing is hence limited to polystyrene particles and possibly other polymeric particles with similar densities and surface hardness ${ }^{43}$. Flow conditions are likely to be different 
around metallic and inorganic particles that have different densities and surface hardness ${ }^{43,44}$, which might affect their ability to interact with phagocytic cells ${ }^{45}$. Additionally, soft particles such as those made of lipids (liposomes) or other self-assembled materials are likely to have varying stabilities under flow conditions. Hence, it remains to be seen whether non-polymeric particles will be taken up by cells that are flowing. The particle shape also influences uptake ${ }^{46}$, and we study particles of one shape (spherical). Future studies will need to examine how particle shape might alter their flow dynamics and affect uptake under fluid flow conditions.

\section{Conclusion}

In conclusion, we show that immune cells are capable of taking up polystyrene particles under flow conditions. The uptake capacity of all phagocytic immune cells tested is either similar or greater under flow than static conditions when presented with sub-micrometer-sized polystyrene particles. However, the uptake capacity is lower while flowing when the cells are presented with larger micro-sized $(\sim 3 \mu \mathrm{m})$ polystyrene particles. Additionally, we show that neutrophils and monocytes are also capable of taking up particles under the crowded conditions of whole blood. These studies reveal that circulating immune cells are likely to have the capacity to take up polymeric particulates injected intravenously, which has potential implications in our design of delivery vehicles that either seek to avoid or target these cells.

\section{Acknowledgments}

We thank G. K. Ananthasuresh for providing the peristaltic pump system. This work was supported by the Dr. Vijaya and Rajagaopal Rao funding for Biomedical Engineering research at the Centre for BioSystems Science and Engineering and the R. I. Mazumdar young investigator position (to SJ). This work was also supported in part by the DBT-Wellcome India Alliance 
bioRxiv preprint doi: https://doi.org/10.1101/2021.04.01.438153; this version posted September 28, 2021. The copyright holder for this preprint (which was not certified by peer review) is the author/funder, who has granted bioRxiv a license to display the preprint in perpetuity. It is made available under aCC-BY-NC 4.0 International license.

Intermediate Fellowship number IA/I/19/1/504265 (to SJ). MS and PS are in receipt of the Kishore Vajgyanik Protsahan Yojana and CSIR senior research fellowship, respectively.

\section{Conflict of Interest}

The authors declare no conflict of interest 


\section{References}

(1) Longmire, M.; Choyke, P. L.; Kobayashi, H. Clearance Properties of Nano-Sized Particles and Molecules as Imaging Agents: Considerations and Caveats. Nanomedicine 2008, 3 (5), 703-717. https://doi.org/10.2217/17435889.3.5.703.

(2) Bae, Y. H.; Park, K. Targeted Drug Delivery to Tumors: Myths, Reality and Possibility. Journal of Controlled Release 2011, 153 (3), 198-205.

https://doi.org/10.1016/j.jconrel.2011.06.001.

(3) Wang, Y.; Grainger, D. W. Barriers to Advancing Nanotechnology to Better Improve and Translate Nanomedicines. Front. Chem. Sci. Eng. 2014, 8 (3), 265-275. https://doi.org/10.1007/s11705-014-1442-x.

(4) Gustafson, H. H.; Holt-Casper, D.; Grainger, D. W.; Ghandehari, H. Nanoparticle Uptake: The Phagocyte Problem. Nano Today 2015, 10 (4), 487-510.

https://doi.org/10.1016/j.nantod.2015.06.006.

(5) Moghimi, S. M.; Hunter, A. C.; Murray, J. C. Long-Circulating and Target-Specific Nanoparticles: Theory to Practice. Pharmacol Rev 2001, 53 (2), 283-318.

(6) Tsoi, K. M.; MacParland, S. A.; Ma, X.-Z.; Spetzler, V. N.; Echeverri, J.; Ouyang, B.; Fadel, S. M.; Sykes, E. A.; Goldaracena, N.; Kaths, J. M.; Conneely, J. B.; Alman, B. A.; Selzner, M.; Ostrowski, M. A.; Adeyi, O. A.; Zilman, A.; McGilvray, I. D.; Chan, W. C. W. Mechanism of Hard-Nanomaterial Clearance by the Liver. Nature Mater 2016, 15 (11), 1212-1221. https://doi.org/10.1038/nmat4718.

(7) Sharma, P.; Sen, D.; Neelakantan, V.; Shankar, V.; Jhunjhunwala, S. Disparate Effects of PEG or Albumin Based Surface Modification on the Uptake of Nano- and Micro-Particles. Biomater. Sci. 2019, 7 (4), 1411-1421. https://doi.org/10.1039/C8BM01545G.

(8) Yin Win, K.; Feng, S.-S. Effects of Particle Size and Surface Coating on Cellular Uptake of Polymeric Nanoparticles for Oral Delivery of Anticancer Drugs. Biomaterials 2005, 26 (15), 2713-2722. https://doi.org/10.1016/j.biomaterials.2004.07.050.

(9) Chithrani, B. D.; Ghazani, A. A.; Chan, W. C. W. Determining the Size and Shape Dependence of Gold Nanoparticle Uptake into Mammalian Cells. Nano Lett. 2006, 6 (4), 662-668. https://doi.org/10.1021/nl052396o.

(10) Champion, J. A.; Walker, A.; Mitragotri, S. Role of Particle Size in Phagocytosis of Polymeric Microspheres. Pharm Res 2008, 25 (8), 1815-1821.

https://doi.org/10.1007/s11095-008-9562-y.

(11) Chen, Y. Y.; Syed, A. M.; MacMillan, P.; Rocheleau, J. V.; Chan, W. C. W. Flow Rate Affects Nanoparticle Uptake into Endothelial Cells. Adv. Mater. 2020, 32 (24), 1906274. https://doi.org/10.1002/adma.201906274.

(12) Nguyen, K. T.; Shukla, K. P.; Moctezuma, M.; Braden, A. R. C.; Zhou, J.; Hu, Z.; Tang, L. Studies of the Cellular Uptake of Hydrogel Nanospheres and Microspheres by Phagocytes, Vascular Endothelial Cells, and Smooth Muscle Cells. J. Biomed. Mater. Res. 2009, 88A (4), 1020-1030. https://doi.org/10.1002/jbm.a.31734.

(13) Yazdimamaghani, M.; Barber, Z. B.; Hadipour Moghaddam, S. P.; Ghandehari, H. Influence of Silica Nanoparticle Density and Flow Conditions on Sedimentation, Cell Uptake, and Cytotoxicity. Mol. Pharmaceutics 2018, 15 (6), 2372-2383.

https://doi.org/10.1021/acs.molpharmaceut.8b00213.

(14) Minasyan, H. Mechanisms and Pathways for the Clearance of Bacteria from Blood Circulation in Health and Disease. Pathophysiology 2016, 23 (2), 61-66.

https://doi.org/10.1016/j.pathophys.2016.03.001.

(15) Smith, B. R.; Ghosn, E. E. B.; Rallapalli, H.; Prescher, J. A.; Larson, T.; Herzenberg, L. A.; Gambhir, S. S. Selective Uptake of Single-Walled Carbon Nanotubes by Circulating 
Monocytes for Enhanced Tumour Delivery. Nature Nanotech 2014, 9 (6), 481-487. https://doi.org/10.1038/nnano.2014.62.

(16) Fromen, C. A.; Kelley, W. J.; Fish, M. B.; Adili, R.; Noble, J.; Hoenerhoff, M. J.; Holinstat, M.; Eniola-Adefeso, O. Neutrophil-Particle Interactions in Blood Circulation Drive Particle Clearance and Alter Neutrophil Responses in Acute Inflammation. ACS Nano 2017, 11 (11), 10797-10807. https://doi.org/10.1021/acsnano.7b03190.

(17) Safari, H.; Kelley, W. J.; Saito, E.; Kaczorowski, N.; Carethers, L.; Shea, L. D.; EniolaAdefeso, O. Neutrophils Preferentially Phagocytose Elongated Particles-An Opportunity for Selective Targeting in Acute Inflammatory Diseases. Sci. Adv. 2020, 6 (24), eaba1474. https://doi.org/10.1126/sciadv.aba1474.

(18) Zhang, Y.; Hughes, K. R.; Raghani, R. M.; Ma, J.; Orbach, S.; Jeruss, J. S.; Shea, L. D. Cargo-Free Immunomodulatory Nanoparticles Combined with Anti-PD-1 Antibody for Treating Metastatic Breast Cancer. Biomaterials 2021, 269, 120666.

https://doi.org/10.1016/j.biomaterials.2021.120666.

(19) Hoshyar, N.; Gray, S.; Han, H.; Bao, G. The Effect of Nanoparticle Size on in Vivo Pharmacokinetics and Cellular Interaction. Nanomedicine 2016, 11 (6), 673-692. https://doi.org/10.2217/nnm.16.5.

(20) Young, R. E.; Thompson, R. D.; Larbi, K. Y.; La, M.; Roberts, C. E.; Shapiro, S. D.; Perretti, M.; Nourshargh, S. Neutrophil Elastase (NE)-Deficient Mice Demonstrate a Nonredundant Role for NE in Neutrophil Migration, Generation of Proinflammatory Mediators, and Phagocytosis in Response to Zymosan Particles In Vivo. J Immunol 2004, 172 (7), 4493-4502. https://doi.org/10.4049/jimmunol.172.7.4493.

(21) Benacerraf, B.; Miescher, P. Bacterial Phagocytosis by the Reticuloendothelial System In Vivo Under Different Immune Conditions. Annals of the New York Academy of Sciences 2006, 88 (1), 184-195. https://doi.org/10.1111/j.1749-6632.1960.tb20018.x.

(22) Tartaro, K.; VanVolkenburg, M.; Wilkie, D.; Coskran, T. M.; Kreeger, J. M.; Kawabata, T. T.; Casinghino, S. Development of a Fluorescence-Based in Vivo Phagocytosis Assay to Measure Mononuclear Phagocyte System Function in the Rat. Journal of Immunotoxicology 2015, 12 (3), 239-246. https://doi.org/10.3109/1547691X.2014.934976.

(23) Sonavane, G.; Tomoda, K.; Makino, K. Biodistribution of Colloidal Gold Nanoparticles after Intravenous Administration: Effect of Particle Size. Colloids and Surfaces B: Biointerfaces 2008, 66 (2), 274-280. https://doi.org/10.1016/j.colsurfb.2008.07.004.

(24) Klarhöfer, M.; Csapo, B.; Balassy, Cs.; Szeles, J. C.; Moser, E. High-Resolution Blood Flow Velocity Measurements in the Human Finger: Blood Flow Velocities in the Human Finger. Magn. Reson. Med. 2001, 45 (4), 716-719. https://doi.org/10.1002/mrm.1096.

(25) Menger, M. D.; Marzi, I.; Messmer, K. In Vivo Fluorescence Microscopy for Quantitative Analysis of the Hepatic Microcirculation in Hamsters and Rats. Eur Surg Res 1991, 23 (3-4), 158-169. https://doi.org/10.1159/000129148.

(26) Taciak, B.; Białasek, M.; Braniewska, A.; Sas, Z.; Sawicka, P.; Kiraga, Ł.; Rygiel, T.; Król, M. Evaluation of Phenotypic and Functional Stability of RAW 264.7 Cell Line through Serial Passages. PLoS One 2018, 13 (6), e0198943. https://doi.org/10.1371/journal.pone.0198943.

(27) Paul, D.; Achouri, S.; Yoon, Y.-Z.; Herre, J.; Bryant, C. E.; Cicuta, P. Phagocytosis Dynamics Depends on Target Shape. Biophysical Journal 2013, 105 (5), 1143-1150. https://doi.org/10.1016/j.bpj.2013.07.036.

(28) Richards, D. M.; Endres, R. G. The Mechanism of Phagocytosis: Two Stages of Engulfment. Biophysical Journal 2014, 107 (7), 1542-1553. https://doi.org/10.1016/j.bpj.2014.07.070. 
(29) Collins, S. J.; Gallo, R. C.; Gallagher, R. E. Continuous Growth and Differentiation of Human Myeloid Leukaemic Cells in Suspension Culture. Nature 1977, 270 (5635), 347349. https://doi.org/10.1038/270347a0.

(30) Yamamoto, N.; Fukai, F.; Ohshima, H.; Terada, H.; Makino, K. Dependence of the Phagocytic Uptake of Polystyrene Microspheres by Differentiated HL60 upon the Size and Surface Properties of the Microspheres. Colloids and Surfaces B: Biointerfaces 2002, 25 (2), 157-162. https://doi.org/10.1016/S0927-7765(01)00306-X.

(31) Heinrich, V. Controlled One-on-One Encounters between Immune Cells and Microbes Reveal Mechanisms of Phagocytosis. Biophysical Journal 2015, 109 (3), 469-476. https://doi.org/10.1016/j.bpj.2015.06.042.

(32) Dynamics of Blood Cell Suspensions in Microflows; Viallat, A., Ed.; CRC Press: Boca Raton, 2020.

(33) Akinc, A.; Battaglia, G. Exploiting Endocytosis for Nanomedicines. Cold Spring Harbor Perspectives in Biology 2013, 5 (11), a016980-a016980.

https://doi.org/10.1101/cshperspect.a016980.

(34) Sousa de Almeida, M.; Susnik, E.; Drasler, B.; Taladriz-Blanco, P.; Petri-Fink, A.; RothenRutishauser, B. Understanding Nanoparticle Endocytosis to Improve Targeting Strategies in Nanomedicine. Chem. Soc. Rev. 2021, 10.1039.D0CS01127D.

https://doi.org/10.1039/D0CS01127D.

(35) Heinrich, V.; Lee, C.-Y. Blurred Line between Chemotactic Chase and Phagocytic Consumption: An Immunophysical Single-Cell Perspective. Journal of Cell Science 2011, 124 (18), 3041-3051. https://doi.org/10.1242/jcs.086413.

(36) Florence, A. T. "Targeting" Nanoparticles: The Constraints of Physical Laws and Physical Barriers. Journal of Controlled Release 2012, 164 (2), 115-124.

https://doi.org/10.1016/j.jconrel.2012.03.022.

(37) May, R. C.; Machesky, L. M. Phagocytosis and the Actin Cytoskeleton. J. Cell Sci. 2001, $114(6), 1061$.

(38) Rinkenauer, A. C.; Press, A. T.; Raasch, M.; Pietsch, C.; Schweizer, S.; Schwörer, S.; Rudolph, K. L.; Mosig, A.; Bauer, M.; Traeger, A.; Schubert, U. S. Comparison of the Uptake of Methacrylate-Based Nanoparticles in Static and Dynamic in Vitro Systems as Well as in Vivo. Journal of Controlled Release 2015, 216, 158-168. https://doi.org/10.1016/j.jconrel.2015.08.008.

(39) Samuel; Jain; O’Dowd; Paul; Kashanin; Gerard; Gunko, Y.; Prina-Mello, A.; Volkov, Y. Multifactorial Determinants That Govern Nanoparticle Uptake by Human Endothelial Cells under Flow. IJN 2012, 2943. https://doi.org/10.2147/IJN.S30624.

(40) Rampado, R.; Crotti, S.; Caliceti, P.; Pucciarelli, S.; Agostini, M. Recent Advances in Understanding the Protein Corona of Nanoparticles and in the Formulation of "Stealthy" Nanomaterials. Front. Bioeng. Biotechnol. 2020, 8, 166. https://doi.org/10.3389/fbioe.2020.00166.

(41) Palchetti, S.; Pozzi, D.; Capriotti, A. L.; Barbera, G. L.; Chiozzi, R. Z.; Digiacomo, L.; Peruzzi, G.; Caracciolo, G.; Laganà, A. Influence of Dynamic Flow Environment on Nanoparticle-Protein Corona: From Protein Patterns to Uptake in Cancer Cells. Colloids and Surfaces B: Biointerfaces 2017, 153, 263-271. https://doi.org/10.1016/j.colsurfb.2017.02.037.

(42) Jayaram, D. T.; Pustulka, S. M.; Mannino, R. G.; Lam, W. A.; Payne, C. K. Protein Corona in Response to Flow: Effect on Protein Concentration and Structure. Biophysical Journal 2018, 115 (2), 209-216. https://doi.org/10.1016/j.bpj.2018.02.036.

(43) Guo, D.; Xie, G.; Luo, J. Mechanical Properties of Nanoparticles: Basics and Applications. Journal of Physics D: Applied Physics 2013, 47 (1), 013001. https://doi.org/10.1088/0022$3727 / 47 / 1 / 013001$. 
(44) Hui, Y.; Yi, X.; Wibowo, D.; Yang, G.; Middelberg, A. P. J.; Gao, H.; Zhao, C.-X. Nanoparticle Elasticity Regulates Phagocytosis and Cancer Cell Uptake. Sci. Adv. 2020, 6 (16), eaaz4316. https://doi.org/10.1126/sciadv.aaz4316.

(45) Yao, C.; Akakuru, O. U.; Stanciu, S. G.; Hampp, N.; Jin, Y.; Zheng, J.; Chen, G.; Yang, F.; Wu, A. Effect of Elasticity on the Phagocytosis of Micro/Nanoparticles. J. Mater. Chem. B 2020, 8 (12), 2381-2392. https://doi.org/10.1039/C9TB02902H.

(46) Champion, J. A.; Mitragotri, S. Role of Target Geometry in Phagocytosis. Proceedings of the National Academy of Sciences 2006, 103 (13), 4930-4934. https://doi.org/10.1073/pnas.0600997103. 